\title{
Numerical-Based Computerized Modelling for Tsunami: Initiating Planning for Natural Disaster of South Kota Denpasar-Bali
}

\author{
Gusti Ayu Made Suartika ${ }^{a},{ }^{*}$, Servasius M. Said ${ }^{a}$, Kadek Edi Saputra ${ }^{a}$ \\ Master Program in Architecture, Universitas Udayana, Jl P. B. Sudirman, Denpasar, 80232, Indonesia \\ Corresponding author: *ayusuartika@unud.ac.id
}

\begin{abstract}
This article addresses planning for natural disaster management. It focuses on composing preventive measures before a natural disaster. Assuming a potential tsunami hitting the coast of Sanur (the southern and eastern coastal-fronts of Kota Denpasar Bali's capital), analysis is grounded by conducting numerical-based computer modeling. It relies on three sets of data: slope, coefficient of surface roughness, and wave height impact. This computer modeling generates scenarios of potential inundation whose catastrophic consequences would have serious impacts on urban life, individuals, and the island's economy. Based on the height of the wave hitting the coast, three scenarios of 5, 10, and 15 Meters are projected. A numerical-based modeling system provides hypothetical data that is then deterministic in analyzing critically impacted urban areas before any spatial-based evacuation scenario can be developed. The study concludes that Denpasar is potentially in a perilous situation. There is a great and present danger that demands impact-based mitigation planning for natural disasters, which is currently absent. Working with a priority, study findings lead to the most urgent need to constitute a plan for tsunami-based mitigation for Serangan Island - one among ten administrative territories of the selected case study - inundation caused by all three scenarios fully submerge that. However, given Denpasar's extensive and encompassing littoral zones, the need for such a plan - for all ten spatial units that come under its administration - is now urgent and of maximum priority.
\end{abstract}

Keywords - Numerical-based computer modelling; tsunami; disaster impact mitigation; inundation; South Kota Denpasar.

Manuscript received 21 Jul. 2020; revised 29 Nov. 2020; accepted 18 Feb. 2021. Date of publication 30 Apr. 2021. IJASEIT is licensed under a Creative Commons Attribution-Share Alike 4.0 International License.

\section{INTRODUCTION}

History documents devastating impacts brought by numerous tsunamis. The most shocking one on the record was December 26, 2004, which hit the country facing the Indian Ocean. It caused more than 230,000 deaths (among them, 167,000 were Indonesians), wiped out hundreds of thousands of houses - home for more than 500,000 dwellers -, and ruined productive farmed land, historical heritages as well as cultural landscapes. While the material consequences were measurable, the psychological impact is unmeasurable [1]. The 2004 tsunami carved an everlasting memory for those who survived the tragedy. It has since taught the world a fundamental lesson of the need for adequate disaster mitigation plans, especially in the Global South countries. In most instances, such a blueprint either did not exist in the first place or failed to function. Hence, such a plan should include a blueprint for before, during, and after a catastrophe [2][3].
This article analyses tsunami impact by calculating the hazards it may cause. It contextualizes this objective for spatial planning practices. Associated hazards are not merely those caused by the level of seawater hitting the inland area but also by many other circumstances. When compiling a Tsunami Risk and Hazard review for New Zealand in 2006, Kelvin Berryman suggested that many factors determine risks brought by a tsunami. These included: 'tsunami generating source (size and frequency of earthquake, landslides, volcanoes); wave propagation through water; flooding of the water across the land (inundation); location and distribution of assets at risk (people, dwellings, other buildings); how easily the assets and people get damaged (fragility)." [4]. The topic discussed below is necessary before an evacuation, and a recovery plan can be proposed.

The selection of South Kota (City) Denpasar as its case study is not merely a random exercise for academic purposes. This focus is critical for several reasons. First, Bali Island, lays on an active ring of fire that makes it seismically vulnerable (Figure 1). This fault line stretches from Bukit Barisan of Sumatra Island and traverses the Lesser Sunda 
Island of the southern part of the Indonesian Archipelago. Second, it is also located on the Indo-Australia and Eurasia plate, which can move at any time and cause a massive displacement of seawater - the instigating event for a tsunami [5]. Third, no study was conducted to measure how vulnerable Kota Denpasar is if a tsunami was to occur. Fourth, Kota Denpasar is absent a disaster mitigation plan that is based on scientifically driven scenarios and calculations. Therefore, this seminal study's importance is unquestionable given its contribution to a responsive disaster mitigation blueprint for Kota Denpasar.

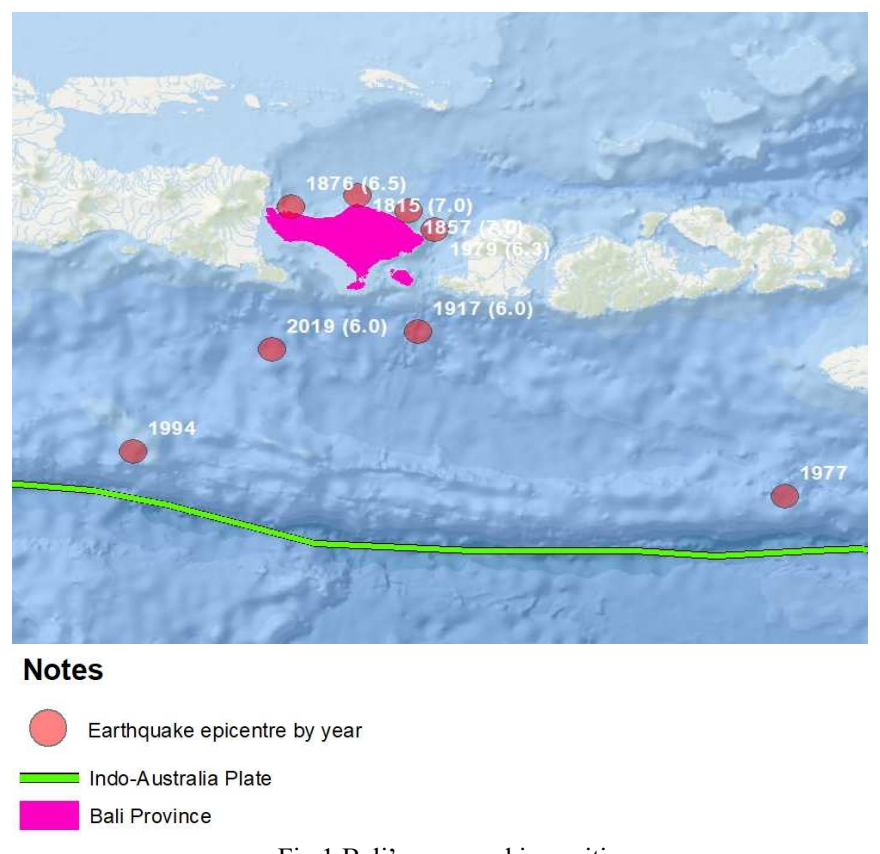

Fig.1 Bali’s geographic position

The study proceeds using computer-based modelling which is supported by data generated from Geographic Information System (GIS). This is facilitated by data pertaining to physical conditions as well as the land utilization of Kota Denpasar. Such modeling provides a scenario as to how certain vulnerable parts of the urban area are to tsunamis [6], [7], [8]. This scenario results from the analysis of the data above with tsunami run-up and inundation. This is not the first study of its kind, as similar research has been carried out. Dedi Sugianto [9] studied potential inundation taking place across Lebak Banten's urban area due to tsunamis. Geographically, Lebak Banten is located on the Southwest of Kota Jakarta (the Capital City of the Indonesian Republic) whose coastal area directly faces the Indonesian Ocean and is therefore exposed to tsunamirelated hazards. Sugianto's study aimed at calculating tsunami run-up that is potentially generated by earthquake and time required for the seawater wave to hit the coast and the surrounding areas. This study used numerical-based modeling and continuity formula. In other words, it generated a model that preceded potential inundation.

In 2018, Nurfitriani [10] also conducted a study of inundation brought by tsunami potentially taking place in the Dulukapa and Deme Villages, of the North Gorontalo Regency, in the Celebes Islands. The northern part of these two villages directly faces the Celebes Sea, placing them prone to tsunami-related calamities. This study estimated the height of tsunami run-up based on a linear tsunami wave principle. It is supported by data generated by the General Bathymetric Chart of the Ocean (GEBCO), released by the United States Geological Survey (USGS). Prior to these two studies, Rudyansyah Putra [11] and Putra Akbar [12] had also conducted their studies of the impact of tsunamis on spatial conditions. Aided with computerized-based analysis, both studies measure the level of risks and vulnerability encountered in a specific terrain on impact.

The Sanur coastline constitutes South Kota Denpasar and offers unique insight into a potential disaster scenario since it directly faces the open sea. This locus of study implements numerical-mathematical-based modeling for tsunamis. It demonstrates the extent to which tsunamis may impact this region. Spatial data required to implement this computer modeling are acquired from and presented in spatial maps using Geographic Information System (GIS). Modeling is divided into three stages, including investigation-of wave generation (run-up), water dispersal, and calculation of potential inundation [13], [14], [15], [16]. In the final stage, identification of flooding depends mainly on the height of run-up (sea waves) hitting Sanur's coastline, the slope, and roughness (resistance) of urban surfaces before inundation [17], [18], [19].

\section{MATERIAL AND METHOD}

Tsunami modeling in this study was simulated using the cost-distance function. To calculate the modeling of propagation or inundation requires a mapping application of ArcGIS. This numerical-based modeling used in this research is sourced from an equation used to study inundation for Hawke's Bay and Wellington in New Zealand [4], where inundation was determined by factors that included the roughness of urban surfaces, the height of sea waves hitting the coast, and the degree of topographic slope of the urban areas [20], [21]. The following equation [22] is used in this study.

$$
\begin{array}{ll}
\text { Notes: } & \\
\text { Hloss } & : \text { The loss of run-up height based on } \\
& \text { 1-meter inundation distance } \\
\mathrm{n} & : \text { Coefficient of surface roughness } \\
\text { Ho } & \begin{array}{l}
\text { : Height of sea wave (run-up) that hit the } \\
\text { coast }
\end{array} \\
\mathrm{S} & : \text { Topographic slope }
\end{array}
$$

Therefore, the Hloss (reduction) depends on two fundamental elements, such as the degree of slope and coefficient of surface roughness. This study implements three scenarios regarding the height of sea waves (Ho) that hit Sanur coastline, which are 5, 10, and 15 meters. These scenarios conform to potentials run-up as determined in the Head Regulation of the Indonesian National Board for Disasters Management, Number 2, the Year 2014 (Peraturan Kepala Badan Nasional Penanggulangan Bencana (Perka PNPB) No 2 Tahun 2014) about the Guide for the Utilization of Specific Resources for Disasters Management. In calculating the coefficient of surface roughness (CRS), Berryman proposes that CRS depends mainly on a specific urban area's land coverage. Table 1 
demonstrates several examples of CRS that vary and are directly associated to urban land uses [10].

TABLE I

COEFFICIENT OF SURFACE ROUGHNESS

\begin{tabular}{llc}
\hline No & Land coverage & $\begin{array}{c}\text { Surface roughness } \\
\text { coefficient }\end{array}$ \\
\hline 1 & Water & 0.007 \\
2 & Bushes & 0.040 \\
3 & Forested area & 0.070 \\
4 & Dried cultivated land & 0.035 \\
5 & Open space & 0.015 \\
6 & Wet cultivated land & 0.025 \\
7 & Housing/settlement & 0.045 \\
8 & Mangrove forest & 0.025 \\
9 & Fish fond & 0.010 \\
\hline
\end{tabular}

Meanwhile, numerical figures regarding the topographic slope are also measured based on land uses analyzed using a spatial raster calculator. When the numerical-computerized modeling for a tsunami run, data on the coefficient of surface roughness (Koef_KP_DBGK1), the topographic slope (slope_deg), and data elevation model for South Denpasar (DEM_Bali) are entered concurrently (Figure 2).

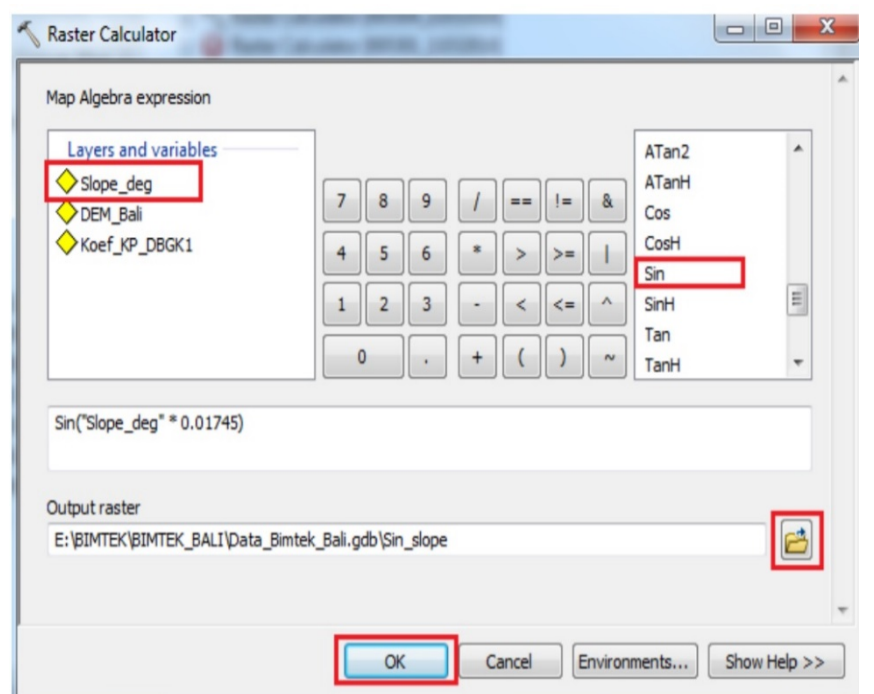

Fig. 2 Slope and the numerical-based computerized modeling

To convert data on the topographic slope into a measurement of 'degree' the value represented in slope deg is converted into radian scale by multiplying it with 0.01745 . This principle is commonly applied in the spatial trigonometric procedure for data represented in degree. Subsequently, this conversion enables the calculation for sin Slope $(\sin S)$ and the Hloos, respectively.

A value of 10 entered (highlighted in red in Figure 3) represents one of the three-wave height scenarios (of 5, 10, and 15 meters) run in this numerical-based modelling for tsunami for South Kota Denpasar. In the end, the value represented in Hloss will be continuously reduced. Based on the three scenarios run here, the wave height difference entered when modeling is run variations in the level of inundation experienced by various urban areas. Certain terrains may be affected by all three sea wave heights, while others may only be affected by one, two sea wave/s, or maybe not at all.

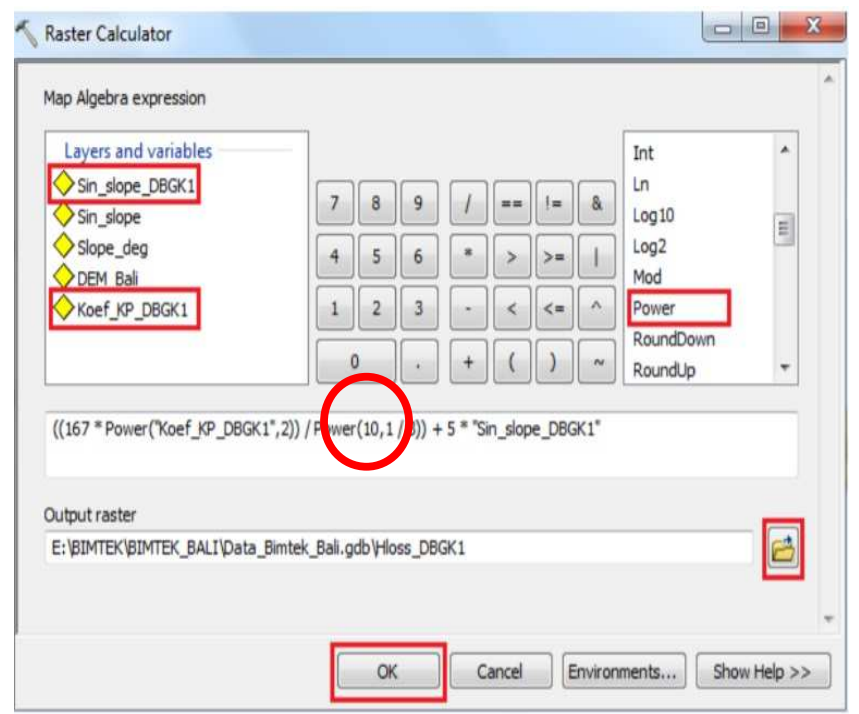

Fig. 3 Sea wave height scenario

\section{RESULTS AND DISCUSSION}

A. Study Locus

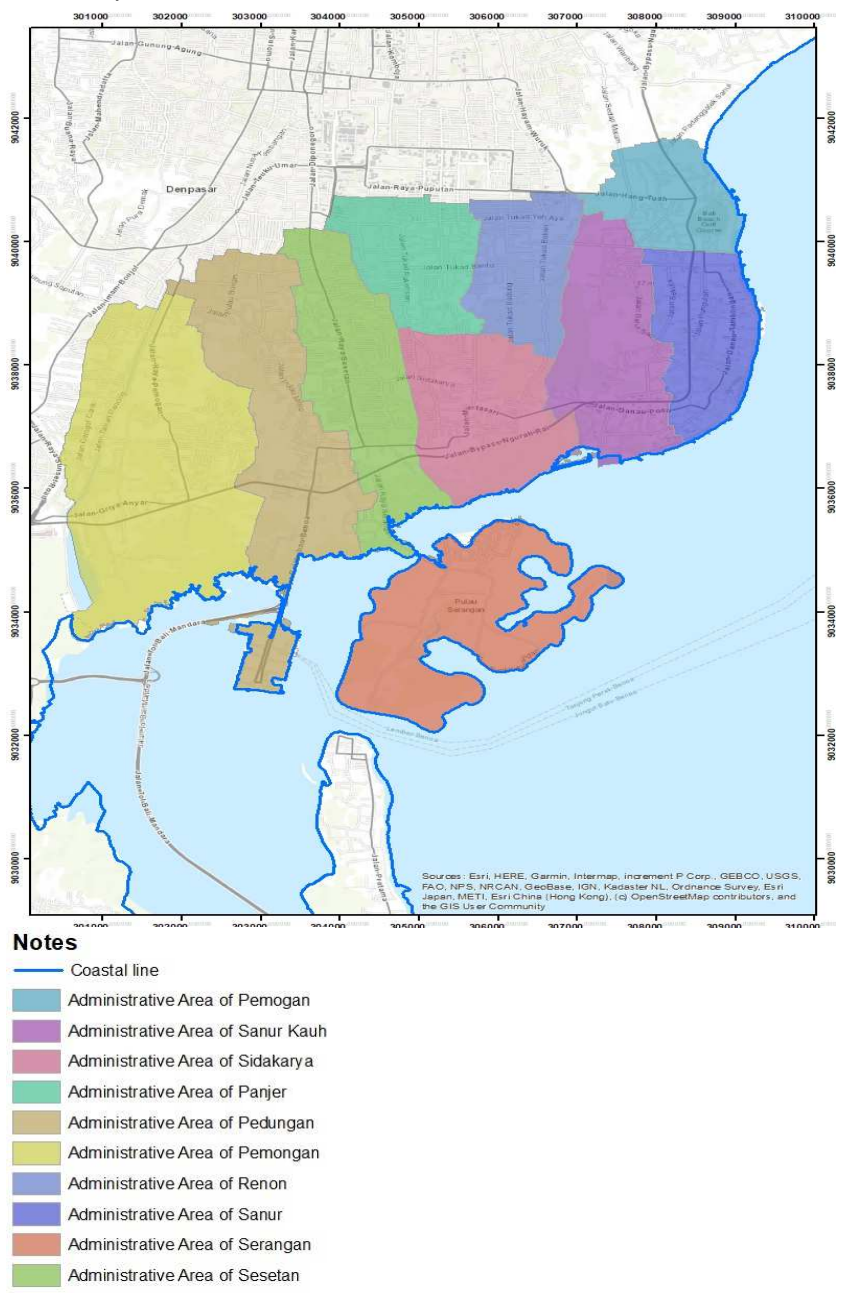

Fig. 4 Study Locus

This research was carried out between August and December 2019 and supported by data acquired from site observations and secondary sources. Its locus concentrates on the coast of Sanur as tsunami generating source and numerous administrative areas of south Kota Denpasar that 
are potentially affected by the tsunami and stretch from North Sanur, West Sanur, Sidakarya, Panjer, Renon, Sanur, Pemogan, Serangan, Sesetan, and Pedungan (Figure 4).

\section{B. Tsunamis in Bali}

Being part of Bali Island - a seismically active Province, Kota Denpasar is susceptible to tsunamis. This was acknowledged in the aftermath of the Aceh Tsunami, which demanded a considered response to tsunami mitigation across the entire Nusantara. Furthermore, history records that tsunamis followed three massive earthquakes that hit Bali. The first took place on November 221815 that according to Arthur Wickman (1918) [23] had a magnitude of $\mathrm{M}=7,0$. It was accompanied by a wave height of 10 meters and an inundation of 500 meters. This calamity caused thousands of lives. The second earthquake happened in 1857. Unfortunately, there is no detailed information available regarding this catastrophic event. The last one was the earthquake of July 14, 1976, whose magnitude was $\mathrm{M}=$
6.5. This disaster, known as Gempa Seririt, affected most of Buleleng and Negara Regencies. It caused 573 deaths, 4,000 injured victims, and 450,000 people who lost their homes. It was followed by a tsunami and catastrophically ruined Bali coastal line's northern part and its surroundings inland.

\section{Land Coverage}

Types of land coverage of the selected case study are demonstrated in Figure 5. This data has been used to determine coefficient surface roughness (CSR) which was used for analysis using tools Arcgis Costdistance when the numerical computerized-based modelling for tsunami inundation was run. Based on data collected from physical surveys and secondary data available at the State Planning and Development Office for Denpasar, 31 percent of South Kota Denpasar is used for settlement. This is the highest percentage of land usage, while the lowest of 3.27 percent is used for commercial and services related purposes.

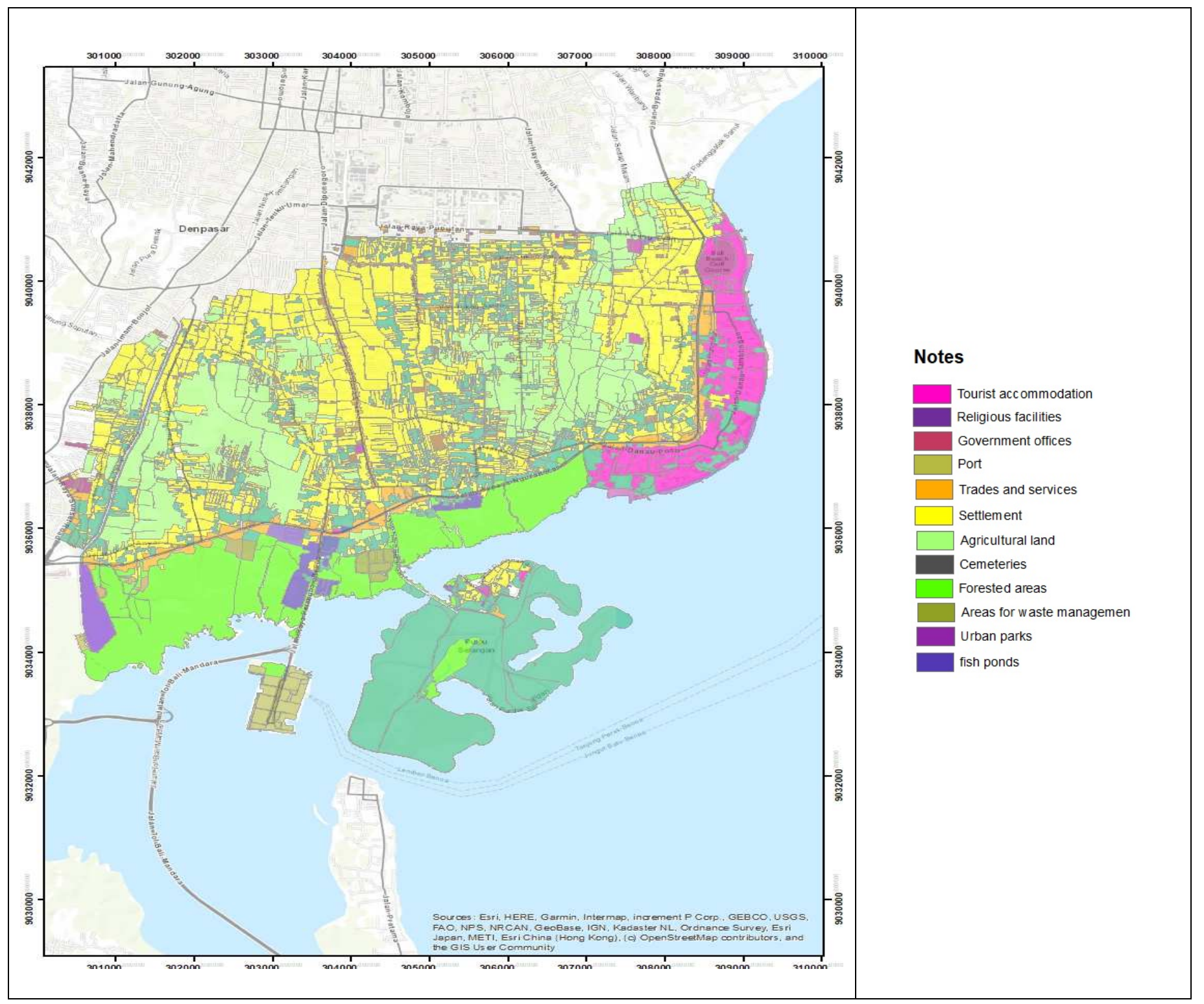

Fig. 5 Land use/coverage 


\section{Coefficient of Surface Roughness (CSR)}

The coefficient of surface roughness (CSR) is directly linked to land coverage over which the sea wave flows. CSR determines the speed of the sea wave as well as the level of inundation a tsunami caused. Based on South Kota Denpasar's existing land coverage (Figure 5) and the CSR presented in Table 1 , the highest CSR is 0.045 covering an area of 1968.57 Hectare or 39.38 percent of the South Kota Denpasar's territory in total. Detailed information on CSR of the rest of the locus study is presented in Figure 6 and Table 2 .

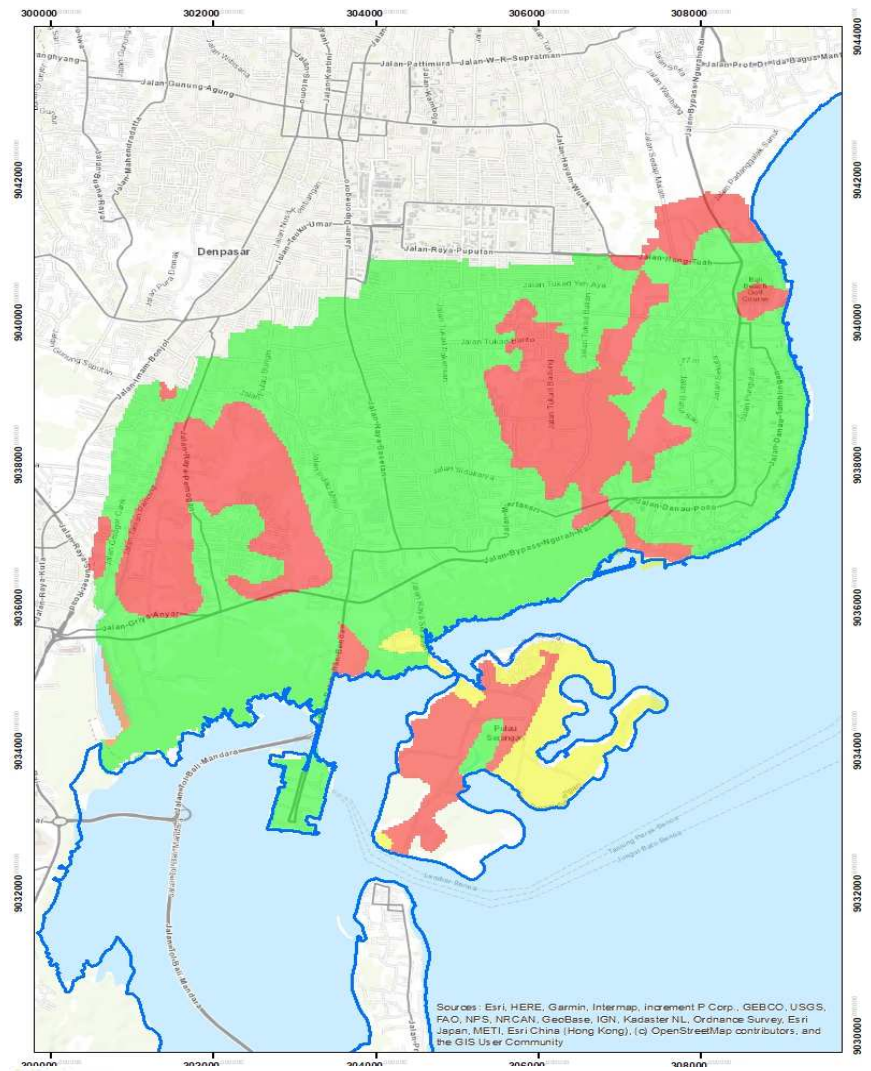

\section{Notes}

Coastal Line

Coefficient of Surface Roughness (CSR)

\section{Value}

- High : 0.045
- Low : 0.002

Fig. 6 Map of CSR of South Kota Denpasar

TABLE II

CSR OF SOUTH KOTA DENPASAR

\begin{tabular}{lcc}
\hline Land coverage (CRS) & $\begin{array}{c}\text { Scale } \\
\text { (Hectare) }\end{array}$ & Percentage \\
\hline Settlement $(0,045)$ & 1968.57 & $39.38 \%$ \\
Farmed area (0,002) & 851.94 & $17.04 \%$ \\
Bushes $(0,004)$ & 527.6 & $10.55 \%$ \\
Unbuilt area $(0,015)$ & 1002.12 & $20.05 \%$ \\
Mangrove forest $(0,025)$ & 649.2 & $12.99 \%$ \\
Total & 4999.43 & $100 \%$ \\
\hline
\end{tabular}

\section{E. Slope}

Data in regard to slope of South Kota Denpasar's terrain referred to in this study is obtained from the State Office for
Planning and Development Board and Information \& Geography Board of Kota Denpasar. This data is presented in percentages, and in the case of the selected case study it has a range between 8 and 45 percent. In this context, territorial slope is classified into five categories. An area with 0-8 percent slope is classified as a very flat; 8-15 percent slope is regarded as a flat; $15-25$ percent is classified as a slightly steep; $25-45$ percent is steep; and $>45$ percent is very steep. Therefore, 34.91 percent of Denpasar's territory falls into the category of a flat area with various slopes ranging from 8 to 15 percent. Meanwhile, only 3.06 percent of this part of town is included in the category of 'steep terrain.' Further variants of this slope are presented in Figure 7 and Table 3.

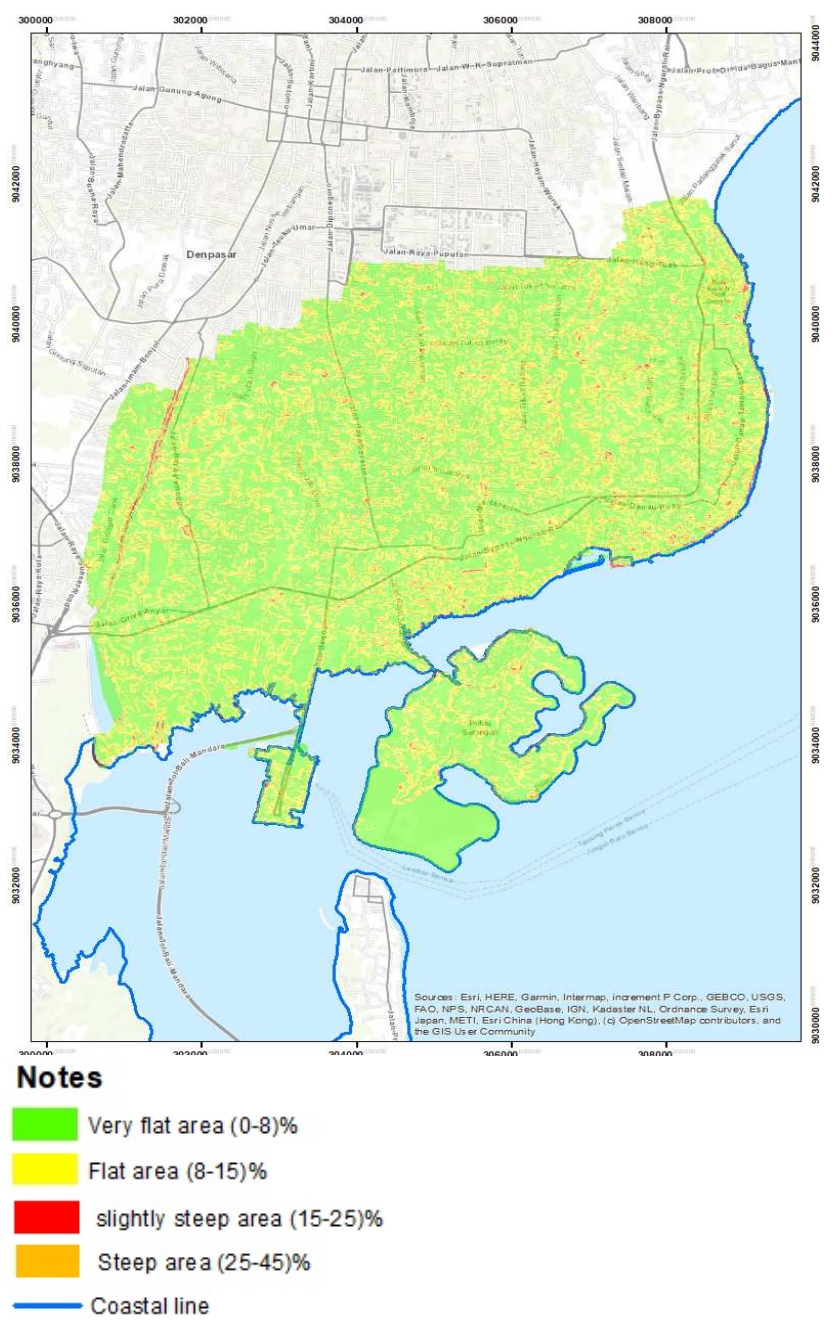

Fig. 7 Map of slope of South Kota Denpasar

TABLE III

SLOPE OF SOUTH KoTA DENPASAR

\begin{tabular}{ccc}
\hline Slope Category & Area (Hectare) & Percent \\
\hline $0-8 \%$ & 1343.16 & 26.87 \\
$8-15 \%$ & 1745.24 & 34.91 \\
$15-25 \%$ & 1162.37 & 23.25 \\
$25-45 \%$ & 595.24 & 11.91 \\
\hline
\end{tabular}

F. Numerical-based Modelling for a 5-Metre Sea Wave Height

The tsunami modeling results with a 5 meter sea wave height demonstrate that flooding will reach 1,924 meters inland, covering an area of 1,450.56 Hectare of South Kota 
Denpasar. The majority of flooded areas would include settlements, large, forested areas, parks, tourist accommodation, trade, and services, as well as vacant land and mangroves. Further detailed areas inundated by this scenario are given in Table 4 and Figure 8.

TABLE IV

INUNDATION FOR A 5 METRE SEA WAVE HEIGHT

\begin{tabular}{clccr}
\hline No & $\begin{array}{l}\text { Administrative } \\
\text { area }\end{array}$ & $\begin{array}{l}\text { Scale of } \\
\text { inundation } \\
\text { (Hectare) }\end{array}$ & $\begin{array}{l}\text { Scale of area } \\
\text { (Hectare) }\end{array}$ & $\begin{array}{l}\text { Percentage } \\
(\mathbf{3}) /(4)\end{array}$ \\
\hline 1 & Sanur Kaja & 59.13 & 257.1631363 & $22.99 \%$ \\
2 & Sanur Kauh & 61.65 & 457.3313209 & $13.48 \%$ \\
3 & Sidakarya & 125.91 & 451.216209 & $27.90 \%$ \\
4 & Panjer & 0 & 313.006179 & $0.00 \%$ \\
5 & Pedungan & 200.07 & 702.1822904 & $28.49 \%$ \\
6 & Pemogan & 212.4 & 1001.489505 & $21.21 \%$ \\
7 & Renon & 0 & 289.0514412 & $0.00 \%$ \\
8 & Sanur & 88.74 & 328.459623 & $27.02 \%$ \\
9 & Serangan & 587.36 & 587.362301 & $100.00 \%$ \\
10 & Sesetan & 115.3 & 520.8071642 & $22.14 \%$ \\
\hline
\end{tabular}

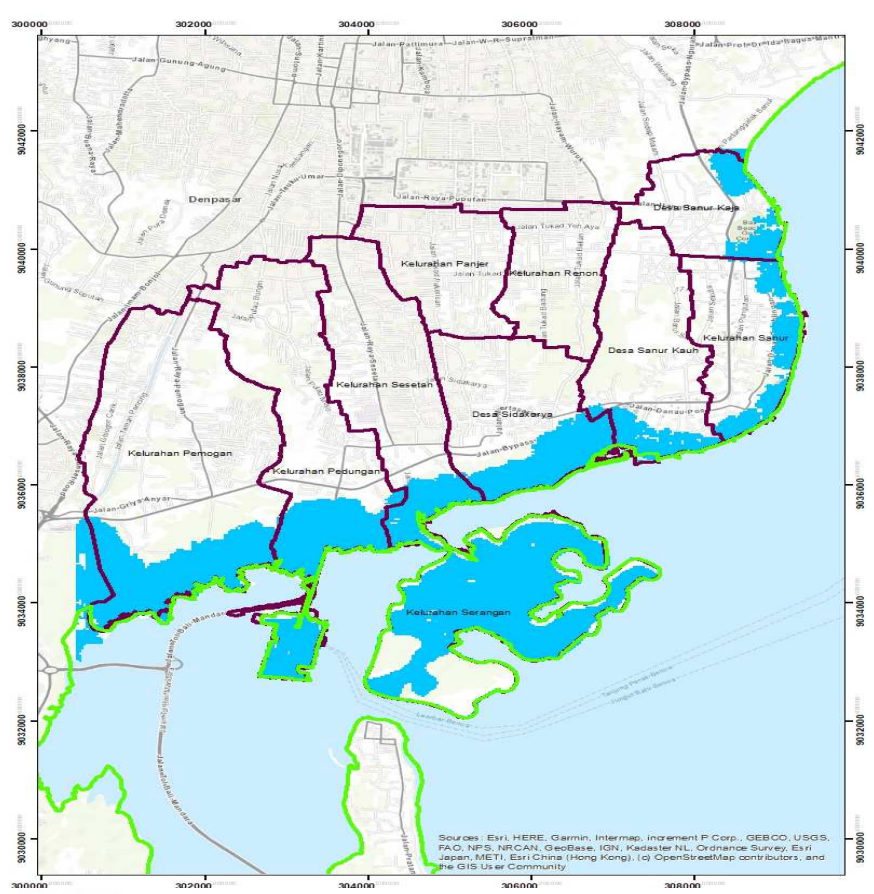

\section{Notes}

inundation

Study Locus

Coastal line

Fig. 8 Inundation map of 5 meter scenario

\section{G. Numerical-based Modelling for a 10-Metre Sea Wave Height}

The results of the tsunami modelling with a sea wave height of 10-meter-reveals that 2,506.43 Hectare of South Kota Denpasar is affected. The difference between the scale of area inundated by the 5 -meter and the 10 -meter sea wave height is $1,055.87 \mathrm{Ha}$. The extent of flooding in this scenario is approximately 3 kilometers from the coastline, extending into residential areas. The majority of inundated areas are paddy fields, vacant land, settlements, forested areas, parks, tourist accommodation, trade and services, as well as vacant land and mangroves. The largest inundation is found in Serangan with a percentage of 100 percent. All other results are presented in Table 5 and Figure 9.

TABLE V

INUNDATION FOR A 10 METRE SEA WAVE HEIGHT

\begin{tabular}{clccr}
\hline No & $\begin{array}{l}\text { Administrative } \\
\text { area }\end{array}$ & $\begin{array}{l}\text { Inundation } \\
\text { scale } \\
\text { (Hectare) }\end{array}$ & $\begin{array}{l}\text { Scale of area } \\
\text { (Hectare) }\end{array}$ & $\begin{array}{l}\text { Percentage } \\
(\mathbf{3}) /(4)\end{array}$ \\
\hline 1 & Sanur Kaja & 239.31 & 257.16313 & $93.06 \%$ \\
2 & Sanur Kauh & 231.75 & 457.33132 & $50.67 \%$ \\
3 & Sidakarya & 284.67 & 451.2162 & $63.09 \%$ \\
4 & Panjer & 0 & 313.0061 & $0.00 \%$ \\
5 & Pedungan & 297.09 & 702.18229 & $42.31 \%$ \\
6 & Pemogan & 429.48 & 1001.4895 & $42.88 \%$ \\
7 & Renon & 49.77 & 289.05144 & $17.22 \%$ \\
8 & Sanur & 257.22 & 328.4596 & $78.31 \%$ \\
9 & Serangan & 587.362301 & 587.3623 & $100.00 \%$ \\
10 & Sesetan & 129.78 & 520.80716 & $24.92 \%$ \\
\hline & & & & \\
\hline
\end{tabular}
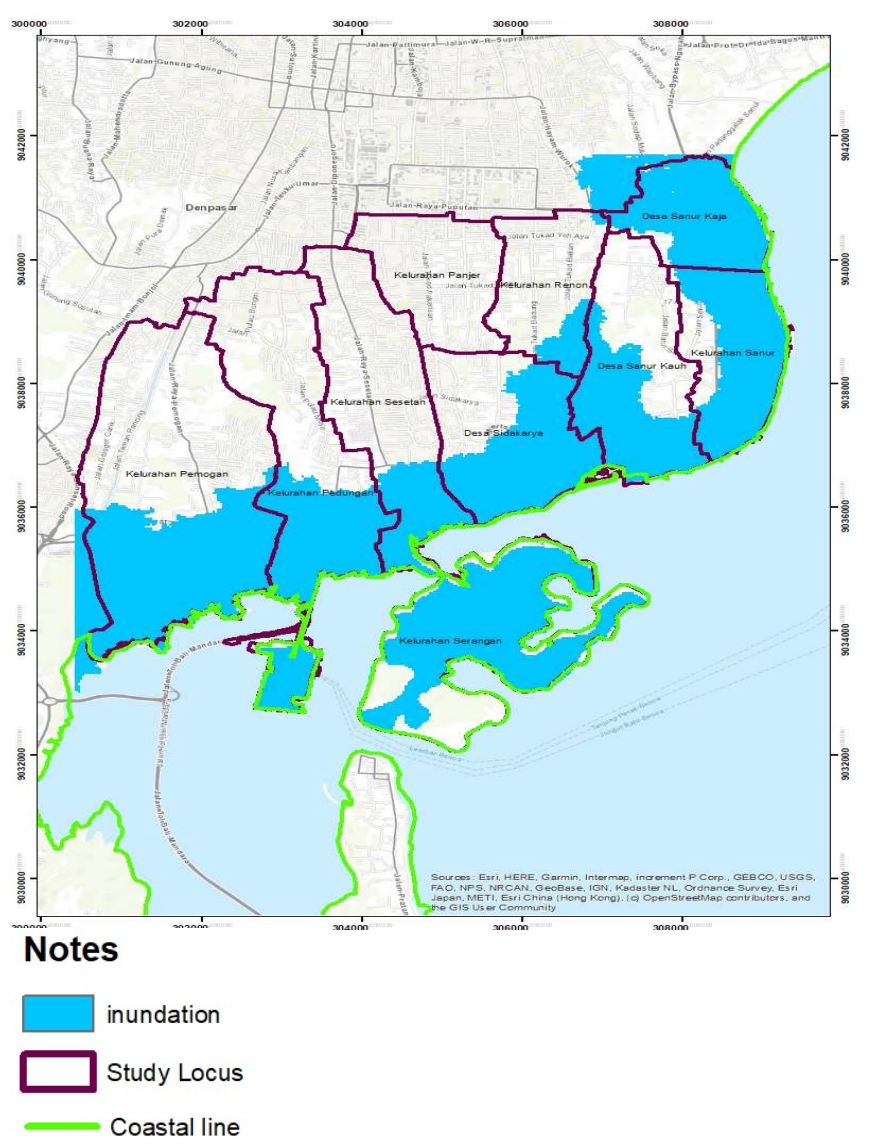

Fig. 9 Inundation map of 10 meter scenario

\section{H. Numerical-based Modelling for a 15-Metre Sea Wave Height}

Tsunami inundation modeling with a sea wave height of 15 meters is classified as a 'very high hazard'. At this level, modeling results indicate that the flooding extends towards the center of Kota Denpasar. The furthest tsunami in the 15meter run-up scenario brings an inundation of four kilometers from the shoreline, flooding an area of 3,726.28 Hectares. This indicates an increase of 1,219.95 Hectares compared to the figure incurred by the 10-meter sea wave height scenario. The majority of areas inundated by this tsunami are government offices, housing, rice fields, vacant land, settlements, grand forest parks, tourism 
accommodation, trade and services, vacant land, and mangroves. Once again, Serangan suffers the most significant consequences, and figures for all other affected areas are demonstrated in Table 6 and Figure 10.

TABLE VI

INUNDATION FOR A 15 METER SEA WAVE HEIGHT

\begin{tabular}{llcrr}
\hline No & $\begin{array}{l}\text { Administrative } \\
\text { area }\end{array}$ & $\begin{array}{l}\text { Scale of } \\
\text { inundation } \\
\text { (Hectare) }\end{array}$ & $\begin{array}{l}\text { Scale of area } \\
\text { (Hectare) }\end{array}$ & \multicolumn{1}{l}{$\begin{array}{l}\text { Percentage } \\
\text { (3)/(4) }\end{array}$} \\
\hline 1 & Sanur Kaja & 255.96 & 257.1631363 & $99.53 \%$ \\
2 & Sanur Kauh & 455.67 & 457.3313209 & $99.64 \%$ \\
3 & Sidakarya & 404.28 & 451.216209 & $89.60 \%$ \\
4 & Panjer & 40.59 & 313.006179 & $12.97 \%$ \\
5 & Pedungan & 451.71 & 702.1822904 & $64.33 \%$ \\
6 & Pemogan & 798.66 & 1001.489505 & $79.75 \%$ \\
7 & Renon & 224.64 & 289.0514412 & $77.72 \%$ \\
8 & Sanur & 328.14 & 328.459623 & $99.90 \%$ \\
9 & Serangan & 587.362301 & 587.362301 & $100.00 \%$ \\
10 & Sesetan & 179.37 & 520.8071642 & $34.44 \%$ \\
\hline
\end{tabular}

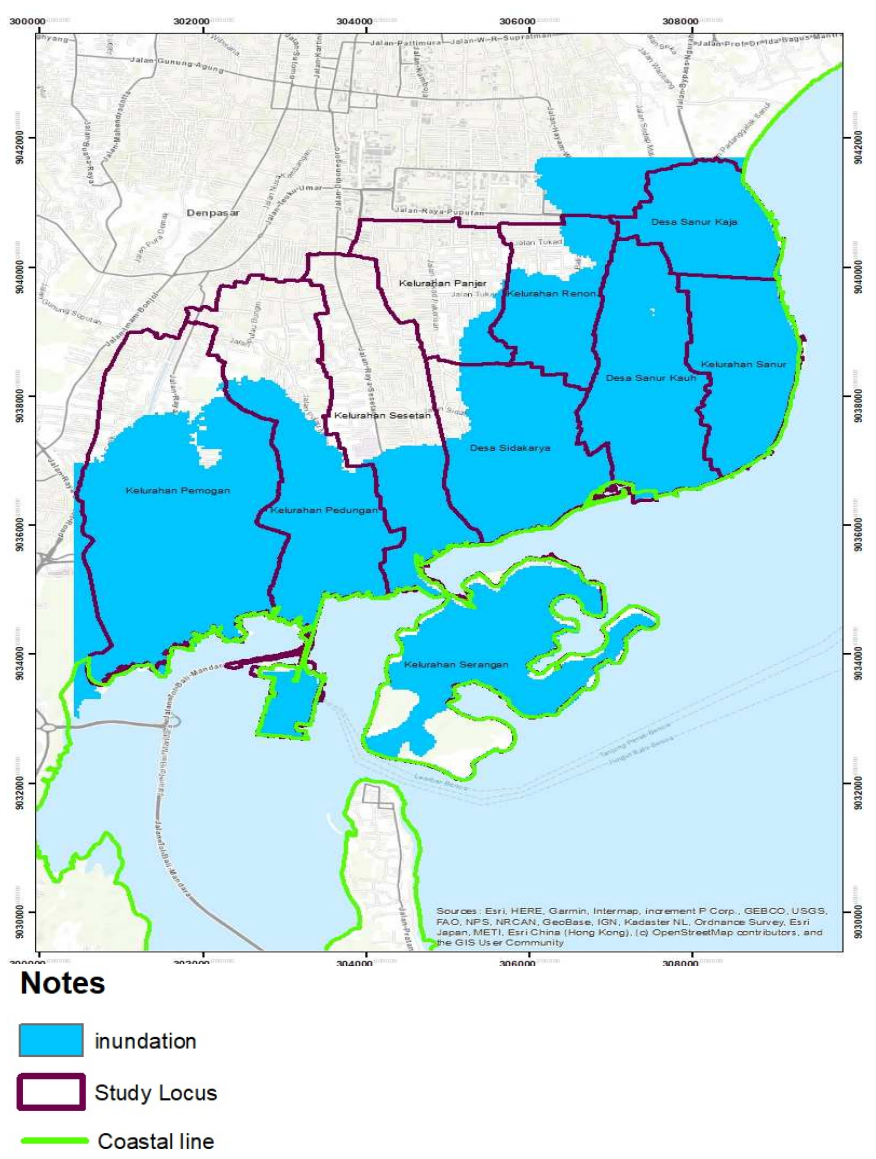

Fig. 10 Inundation map of 15 meter scenario

\section{CONCLUSIONS}

While it has not been our intention here to be predictive of land use change, hazard reduction mechanisms, and safety procedures, it is clear from the study findings presented above, that significant assessment of planning for disaster mitigation and environmental policies are suggested. There are also implications from urban planning policy about the readiness of hospital and other infrastructures to deal with tsunami victims - a different kind of disaster to the current condition of a Covid-19 pandemic, for instance. Bali's costs gaining an international reputation of potentially being an unsafe place for foreign tourism and investment could far outweigh the immediate damage to life and property. The Coronavirus is a warning that other disasters may abound.

The numerical-based modelling for tsunamis documented in this article has demonstrated varying levels of inundation caused by three sea wave height scenarios that could potentially hit the South Denpasar coastline. Each scenario causes a different level of alarm to sound for the inland areas of South Kota Denpasar. As demonstrated, the 15 meter scenario causes an enormous inundation that reaches the heart of the city, submerging almost all administrative areas of South Kota Denpasar, with potentially destructive effects both economically, environmentally, and in terms of human life. It also induces impacts across the entire range of land uses - settlements, trade and services, offices, cultivation land, and protected land. Thus, results generated from this study have provided an enduring insight into nature's potentially destructive capacity.

In the face of global warming, such hazards cannot be overlooked. Rising seawater, the fragility and movability of the world plates, and the geographical position of Bali Island on the ring of fire are omnipresent [24]. Bali is in great need of a responsive disaster management plan that addresses the potential hazards brought about by a tsunami. So, we respectively suggest that the study findings presented here should be seriously considered and appropriate responses are undertaken as a matter of extreme urgency.

\section{ACKNOWLEDGMENT}

We are grateful to Professor Alexander Cuthbert for the constructive feedback and guidance that have made this publication possible. Research Grants have supported this article's production provided to authors by Udayana University and the Indonesian Ministry for National Education and Culture - the Indonesian Ministry of Research and Technology - (National Research and Innovation Board).

\section{REFERENCES}

[1] BBC News, "Indian Ocean tsunami anniversary: Memorial events held," https://www.bbc.com/ news/ world-asia-30602159, December 26, 2014.

[2] G. A. M. Suartika, N. P. D. A. Permanasuri, and K. E. Saputra, "Provision Of a Sustainable Public Space: Lebih Coastal Area in the Aftermath of Rampant Abrasions," IOP Conf. Ser. Earth Environ. Sci., vol. 396, no. 1, 2019, doi: 10.1088/1755-1315/396/1/012029.

[3] G. A. M. Suartika, "Sand, Sea and Ceremony: Conflict over the Littoral Public Realm in Sanur, Bali," Procedia - Soc. Behav. Sci., vol. 179, pp. 128-140, 2015, doi: 10.1016/j.sbspro.2015.02.416.

[4] K. Berryman, Review of Tsunami Hazard and Risk in New Zealand. New Zealand: Institute of Geological and Nuclear Sciences, 2006.

[5] N. Rakowsky and A. Immerz, "How vulnerable is the coast of Bali? Tsunami simulations for Indonesia," [Online]. Available: https://www.eskp.de/en/natural-hazards/tsunami-simulations-forindonesia-935979.

[6] T. Takabatake, P. St-Germain, I. Nistor, J. Stolle, and T. Shibayama, "Numerical modelling of coastal inundation from Cascadia Subduction Zone tsunamis and implications for coastal communities on western Vancouver Island, Canada," Nat. Hazards, vol. 98, no. 1, pp. 267-291, 2019, doi: 10.1007/s11069-019-03614-3.

[7] A. Piatanesi and S. Tinti, "Numerical modelling of the September 8, 1905 Calabrian (southern Italy) tsunami," Geophys. J. Int., vol. 150, 
no. 1, pp. 271-284, 2002, doi: 10.1046/j.1365-246X.2002.01700. x.

[8] X. Wang and P. L.-F. LIU, "Numerical Simulations of the 2004 Indian Ocean Tsunamis - Coastal Effects," J. Earthq. Tsunami, vol 01, no. 03, pp. 273-297, 2007, doi: 10.1142/s179343110700016x.

[9] D. Sugianto, I. W. Nurjaya, N. MN Natih, and W. W. Pandoe, "Potensi Rendaman Tsunami di Wilayah Lebak Banten," J. Kelaut. Nas., vol. 12, no. 1, p. 9, 2017, doi: 10.15578/jkn. v12i1.6241.

[10] Nurfitriani, M. Gybert E., R. Djamaluddin, and T. Yatimantoro, "Analisis potensi rambatan tsunami di Pantai Utara Desa Dulukapa dan Deme 1 Kabupaten Gorontalo Utara untuk mitigasi bencana tsunami," J. Maj. Ilm. Globe, vol. 20, no. 2, pp. 67-76, 2018.

[11] R. Putra, "Kajian risiko tsunami terhadap bangunan gedung nonhunian dengan skenario variasi ketinggian run-up pada garis pantai (studi kasus: Kota Banda Aceh, Indonesia)," Thesis Pascasarj. UGM, p. 174, 2008, doi: 10.14710/pwk. v9i2.6534

[12] P. Akbar, "Tingkat risiko bencana tsunami dan variasi spasialnya "studi kasus Kota Padang, Sumatra Barat," Thesis Megister Ilmu Geogr. Wil. dan Kota Univ. Indones., 2010.

[13] R. A. Pratomo and I. Rudiarto, "Permodelan Tsunami dan Implikasinya Terhadap Mitigasi Bencana di Kota Palu," J. Pembang. Wil. Kota, vol. 9, no. 2, p. 174, 2013, doi: 10.14710/pwk. v9i2.6534.

[14] R. C. Smith et al., "Comparing approaches for numerical modelling of tsunami generation by deformable submarine slides," Ocean Model., vol. 100, pp. 125-140, 2016, doi: 10.1016/j.ocemod.2016.02.007.

[15] F. Dias, D. Dutykh, L. O'Brien, E. Renzi, and T. Stefanakis, "On the modelling of tsunami generation and tsunami inundation," Procedia IUTAM, vol. 10, pp. 338-355, 2014, doi: 10.1016/j.piutam.2014.01.029.

[16] R. Weiss, K. Wünnemann, and H. Bahlburg, "Numerical modelling of generation, propagation and run-up of tsunamis caused by oceanic impacts: Model strategy and technical solutions," Geophys. J. Int. vol. 167, no. 1 , pp. 77-88, 2006, doi: 10.1111/j.1365
246X.2006.02889. x.

[17] T. I. H. Rahiman, J. R. Pettinga, and P. Watts, "The source mechanism and numerical modelling of the 1953 Suva tsunami, Fiji," Mar. Geol., vol. 237, no. 1-2, pp. 55-70, 2007, doi: 10.1016/j.margeo.2006.10.036

[18] J. Xie, I. Nistor, and T. Murty, "Tsunami risk for Western Canada and numerical modelling of the Cascadia fault tsunami," Nat. Hazards, vol. 60, no. 1, pp. 149-159, 2012, doi: 10.1007/s11069011-9958-6.

[19] A. Santos, A. O. Tavares, and M. Queirós, "Numerical modelling and evacuation strategies for tsunami awareness: lessons from the 2012 Haida Gwaii Tsunami," Geomatics, Nat. Hazards Risk, vol. 7, no. 4, pp. 1442-1459, 2016, doi: 10.1080/19475705.2015.1065292.

[20] C. N. Whittaker, R. I. Nokes, H. Y. Lo, P. L. F. Liu, and M. J. Davidson, "Physical and numerical modelling of tsunami generation by a moving obstacle at the bottom boundary," Environ. Fluid Mech., vol. 17, no. 5, pp. 929-958, 2017, doi: 10.1007/s10652-017-9526-z.

[21] A. Prasetyo, T. Yasuda, T. Miyashita, and N. Mori, "Physical modeling and numerical analysis of tsunami inundation in a coastal city," Front. Built Environ., vol. 5, no. April 2019, doi: 10.3389/fbuil.2019.00046

[22] M. McSaveney and M. Rattenbury, "Tsunami impact in Hawke's Bay," Inst. Geol. Nucl. Sci., vol. 10, no. December, pp. 0-12, 2000.

[23] "https://www.ngdc.noaa.gov/nndc/struts/ results?bt $0=1815 \&$ st $0=2011 \&$ type 8 None+Selected\&op_14 $=$ eq\&v_14=INDONESIA\&st_1 $1=-$ 6\&bt_2=114\&st_2=116\&bt_1=-

$9 \&$ bt $10=\&$ st $10=\&$ ge $9=\&$ le $9=\&$ bt $3=\&$ st $3=\&$ type $19=$ EXAC T\&query_19=-None+Selected\&op_17=eq\&v_17."

[24] T. Matsui, F. Imamura, E. Tajika, Y. Nakano, and Y. Fujisawa, "Generation and propagation of a tsunami from the CretaceousTertiary impact event," Spec. Pap. Geol. Soc. Am., vol. 356, no. December, pp. 69-77, 2002, doi: 10.1130/0-8137-2356-6.69. 